\title{
NOMENCLATURAL ADJUSTMENTS IN PHACELIA SECT. GLANDULOSAE (HYDROPHYLLACEAE, BORAGINALES)
}

\author{
Genevieve K. Walden ${ }^{1}$, Laura M. Garrison ${ }^{2}$, and Robert Patterson ${ }^{3}$
}

\begin{abstract}
AвSTRACT.-Three taxa are recognized at the rank of species based on molecular phylogenetic studies in Phacelia sect. Glandulosae (Hydrophyllaceae, Boraginales). Results of those studies did not support a monophyletic Phacelia crenulata Torr. ex S. Watson, because 3 varieties of that species were supported as distinct lineages based on molecular (nuclear and chloroplast) and morphological characters. Typification and status is clarified for $P$. corrugata A. Nelson and $P$. orbicularis Rydb. A new nomenclatural combination for P. crenulata var. angustifolia N.D. Atwood is established to elevate that variety to species rank, as Phacelia angustifolia (N.D. Atwood) Walden, comb. et stat. nov.
\end{abstract}

Resumen.-Tres taxones son reconocidos en el rango de las especies sobre la base de los estudios filogenéticos moleculares en Phacelia sect. Glandulosae (Hydrophyllaceae, Boraginales). Los resultados de estos estudios no apoyaron un monofilético Phacelia cremulata Torr. ex S. Watson, tres variedades de esta especie fueron apoyados como linajes distintos basados en caracteres moleculares (nuclear y cloroplasto) y morfológicos. Tipificación y el estatus se aclara para P. corrugata A. Nelson y $P$. orbicularis Rydb. Una nueva combinación de nomenclatura para P. crenulata var. angustifolia N.D. Atwood se establece elevar esa variedad al rango de especie, como Phacelia angustifolia (N.D. Atwood) Walden, comb. et stat. nov.

Phacelia crenulata Torr. ex S. Watson (sensu Atwood 2003) has been accepted to include 6 varieties: var. angustifolia N.D. Atwood, var. ambigua (M.E. Jones) J.F. Macbr., var. corrugata (A. Nelson) Brand, var. crenulata, var. minutiflora (Munz) Jeps., and var. orbicularis (Rydb.) N.D. Atwood (Atwood 1975, 2003, Patterson et al. 2012, Walden et al. 2013). However, molecular phylogenetic studies (Garrison 2007, Walden 2010, Walden et al. 2014, Walden unpublished data) of Phacelia sect. Glandulosae (Rydb.) Walden \& R. Patt. (Walden and Patterson 2012) have not supported a monophyletic P. crenulata (sensu Atwood 2003). Three taxa were separated from the clade corresponding to typical $P$. crenulata (Walden et al. 2014), which demonstrated that these lineages (i.e., var. angustifolia, var. corrugata, and var. orbicularis) would be best treated at species rank. Formal recognition of these taxa as separate species is proposed here. Phacelia crenulata var. angustifolia does not have an existing name at species rank, so both a change in status and a new combination are proposed. The other 2 varieties were originally described at species rank by Nelson (1902) and Rydberg (1913), and those names remain available for use: Phacelia corrugata A. Nelson and P. orbicularis Rydb.

Phacelia ambigua M.E. Jones $[=$ P. crenulata var. ambigua (M.E. Jones) J.F. Macbr.] has been treated as a separate species by Atwood (1972a, 1975, 1976, 2003), but molecular phylogenetic studies have placed the western North American (i.e., Arizona and California) populations of this taxon in the $P$. crenulata clade, which consisted of samples corresponding to P. crenulata var. ambigua (M.E. Jones) J.F. Macbr., P. crenulata var. crenulata, and $P$. crenulata var. minutiflora (Munz) Jeps. (Garrison 2007, Hansen et al. 2009, Walden 2010, Walden et al. 2014). A revision of $P$. crenulata and varieties (var. ambigua, var. crenulata, and var. minutiflora) will be resolved in a future systematic paper.

\section{BACKGROUND}

Phacelia crenulata var. angustifolia was described in Atwood's (1975) comprehensive revision of $P$. cremulata and relatives, and later treated as a variety of $P$. crenulata (Atwood 2003). Although no names interfere with changing the status of $P$. crenulata var. angustifolia to species rank, there is a previously published

${ }^{1}$ Department of Integrative Biology, University of California, Berkeley, CA; University and Jepson Herbaria, University of California, Berkeley, CA. E-mail: gkwalden@gmail.com

${ }^{2}$ Department of Ecology and Evolutionary Biology, Brown University, Providence, RI.

${ }^{3}$ Department of Biology, San Francisco State University, 1600 Holloway Avenue, San Francisco, CA. 
name in Phacelia with the epithet "angustifolia" at rank forma that warrants mention, but confusion about the application of that name is unlikely. Brand's (1913) forma (P. magellanica [Lam.] Coville forma angustifolia Brand) is a synonym of $P$. hastata Douglas ex Lehm. var. hastata (Heckard 1960). Howell annotated collections with Brand's name (e.g., Howell 28807 CAS), as did Kruckeberg, who evidently considered elevating the name to species rank ("Phacelia angustifolia" in. ed.) but never published that name, and those specimens eventually received determinations with the subsequently published name $P$. capitata Kruckeb. (Kruckeberg 1956, Shelly 1989).

Nelson (1902) included 2 collections in the protologue for P. corrugata. Osterhout was the "type" and Crandall was the "co-type" (Nelson 1902, p. 27). Osterhout is the effective type collection, and Crandall is the effective paratype collection, determined by Nelson in the original publication, working at the Rocky Mountain Herbarium (RM). Nelson attached correction labels with the published names to the type specimen and the co-type specimen at RM, which makes the type specimen (Osterhout 2129, RM23616-002821) the effective holotype.

However, because there are now multiple sheets at RM for these collections, and some of the details now required were not included in the original publication, there has been some confusion regarding typification. The other sheets were received at RM after the 1902 publication (e.g., RM0002822 in 1904). Osterhout gifted his entire herbarium to RM in 1937, and his personal sheets were incorporated into RM after that time (e.g., RM000283 in 1938). Brand (1913) added the details for the collection numbers in his revision of Hydrophyllaceae (Osterhout 2129 and Crandall 4174). Voss (1937a, 1937b) examined specimens of both collections at NY for his revision of the group, indicating that Osterhout was the type collection and citing the Crandall collection, but this did not mean that the NY sheet was the type specimen or that it was an intentional lectotypification. There is no evidence of annotations or other notes that Voss would have provided on the NY sheets for a typification. Atwood (1972b, 1975) has sometimes been considered to have effected lectotypification by selecting a sheet among the several deposited at RM as the holotype.
However, Atwood, like Brand and Voss, was following the choice of Nelson. Lectotypification is not needed in this case. Because the Crandall collection has sometimes been considered a syntype in the literature, and as it likely provided additional flowering characters for the description, its details are also included in the taxonomic section. We were particularly excited to find specimens in online databases that had not previously been cited in the literature, and expect to find additional specimens as databasing and digitization efforts continue to progress rapidly (e.g., Consortium of Intermountain Herbaria [CIH 2015], Consortium of Pacific Northwest Herbaria [CPNWH 2015], C.V. Starr Virtual Herbarium [20102016], Southwestern Environmental Information Network [SEINet 2012-2016]).

Phacelia orbicularis was treated as a synonym of $P$. corrugata by Atwood (1972b, 1975, 1976), and later as a variety of $P$. crenulata (Atwood 2003). Rydberg (1913) indicated the location of the type specimen (Jones 4663) in the protologue as "type in U.S. Nat. Herb." Voss (1937b) stated that the only material known was from the type (US) and did not indicate a sheet at NY for his revision. The label of the isotype specimen, a fragment deposited at NY, reiterates this statement ["type in U.S. Nat. Herb."]. Atwood annotated these specimens twice. The holotype (US) was annotated in 1971 and again in 1998. The isotype (NY) was annotated in 1971 as the isotype and as a type fragment in 1998. Atwood (1972b, 1975) previously cited the holotype at US, but an error made during publication of $P$. crenulata var. orbicularis transposed the locations of the holotype specimen (NY) and the isotype (US) (Atwood 2003). We provide the corrected locations in the taxonomic treatment here.

\section{Taxonomic Treatment}

Phacelia angustifolia (N.D. Atwood) Walden, comb. et stat. nov. Not Phacelia magellanica [Lam.] Coville forma angustifolia Brand, 1919. Phacelia crenulata Torr. ex S. Watson var. angustifolia N.D. Atwood, Great Basin Naturalist 35(2):158-159, f. 28, map 11. 1975. TYPE: USA, Arizona, Coconino County, small mesas just north of Wapatki National Monument Headquarters, sandy soil covered with [a little] volcanic ash, 
18 May 1970, N.D. Atwood 2597 (holotype: BRY not seen; isotypes: CAS980935!, US334584 digital image!, NY00074081 digital image!, ASU203838 not seen, UCR 94522 not seen, UTC217811!, GH53262 not seen, TEX0000362 digital image!).

Phacelia corrugata A. Nelson, Botanical Gazette 34: 26. 1902. Phacelia crenulata Torr. ex S. Watson var. corrugata (A. Nelson) Brand, p. 79 in A. Engler (editor), Das Pflanzenreich IV, Vol. 251 (Heft 59). Wilhelm Engelmann, Leipzig. 1913. TYPE: USA, Colorado, Garfield County, Rifle, 23 June 1900, G.E. Osterhout 2129 (holotype: RM23616-002821 [type annotated by Nelson] digital image!; isotypes NY00337197 digital image!, RM not seen, WISv0256083WIS digital image!, BRYV0001347 not seen). PARATYPE: USA, Colorado, Mesa County, Palisades, in full bloom, altitude 4750 feet, 14 May 1898, C.S. Crandall 4194 (RM0002824 [co-type annotated by Nelson] digital image!, RM000283 digital image!, RM0002822 digital image!, US not seen, CS17036 not seen).

Phacelia orbicularis Rydb., Bulletin of the Torrey Botanical Club 40:479. 1913. Phacelia crenulata Torr. ex S. Watson var. orbicularis (Rydb.) N.D. Atwood, Utah Fl., ed. 3, p. 334. 2003. TYPE: USA, Utah, [Garfield County, Marvin Mts.] Marvin Laccolite, $6000 \mathrm{ft}, 2$ July 1894, M.E. Jones 5663 (holotype US326859 digital image!; isotype: NY0083890 [fragment] digital image!).

\section{ACKNOWLEDGMENTS}

We especially thank Bruce Baldwin, whose comments and suggestions greatly improved this manuscript. We also thank the editors and 2 anonymous reviewers for their thoughtful comments and insight. This article is based on thesis work by LMG (2007) and by GKW (2010), and is in support of the Flora of North America (north of Mexico) treatment of Phacelia by GKW and RP.

\section{Literature Cited}

ATwood, N.D. 1972a. A revision of the Phacelia Crenulatae group (Hydrophyllaceae) for North America. Doctoral dissertation, Brigham Young University, Provo, UT

ATwood, N.D. 1972b. New species in the Phacelia Crenulatae group (Hydrophyllaceae). Rhodora 74:451-468.
ATwood, N.D. 1975. A revision of the Phacelia Crenulatae group (Hydrophyllaceae) for North America. Great Basin Naturalist 35:127-190.

ATwood, N.D. 1976. The Hydrophyllaceae of Utah. Great Basin Naturalist 36:1-55.

Atwood, N.D. 2003. Hydrophyllaceae. Pages 327-339 in S.L. Welsh, N.D. Atwood, S. Goodrich, and L.C. Higgins, editors, A Utah Flora. 3rd edition, revised. Brigham Young University, Provo, UT.

Brand, A. 1913. Hydrophyllaceae. Pages 1-210 in Adolf Engler, editor, Das Pflanzenreich IV. Volume 251 (Heft 59).Wilhelm Engelmann, Leipzig, Germany.

[CIH] CONSORTIUM OF InTERMOUNTAIN Herbaria IN COLLABORATION WITH THE SOUTHWESTERN ENVIRONMENTAL InFORMATION NETWORK (SEINET). 2015. Intermountain Regional Herbarium Network. Herbarium specimen data provided by Brigham Young University Herbarium and Intermountain Herbarium. [Accessed 1 February 2016]. http://intermountainbiota.org

[CPNWH] CONSORTIUM OF PACIFIC NORThwest Herbaria. 2015. Herbarium specimen data provided by B.A. Bennett Herbarium, Yukon Government (BABY); Boise District Bureau of Land Management (BBLM); Boise State University, Snake River Plains Herbarium (SRP); Bureau of Land Management, Medford District (BLMMD); College of Idaho, Harold M. Tucker Herbarium (CIC); Eastern Washington University (EWU); Evergreen State College (EVE); Friday Harbor Laboratories (FHL); H.J. Andrews Experimental Forest (HJAEF); Humboldt State University (HSC); Idaho State University, Ray J. Davis Herbarium (IDS); Linfield College (LINF); Milner Gardens and Woodland, Vancouver Island University (VIU); Montana State University (MONT); Oregon State University (OSC); Pacific Lutheran University (PLU); Pacific Northwest Herbarium, Western Washington University (WWB); Portland State University (HPSU); Reed College (REED); Royal British Columbia Museum (V); Southern Oregon University (SOC); The New York Botanical Garden (NY); University of Alaska, Anchorage (UAAH); University of Alaska, Fairbanks - Museum of the North (ALA); University of British Columbia (UBC); University of Idaho, Stillinger Herbarium (ID); University of Lethbridge (LEA); University of Montana (MONTU); University of Puget Sound (PSM); University of Washington (WTU); University of Wyoming, Rocky Mountain Herbarium (RM); Washington State University, Marion Ownbey Herbarium (WS); Whitman College (WCW). [Accessed through the Consortium of Pacific Northwest Herbaria web site 2015]. http://www.pnwherbaria.org

C.V. Stark Virtual Herbarium. 2010-2016. Herbarium @ NYGB. Gateway to the digitized specimens of the William and Lynda Steere Herbarium; [accessed 2010-2016]. http://sweetgum.nybg.org/science/vh

Garrison, L.M. 2007. Phylogenetic relationships in Phacelia (Boraginaceae) inferred from nrITS sequence data. Master's thesis, San Francisco State University, CA.

Hansen, D.R., G.S. Spicer, and R. Patterson. 2009. Phylogenetic relationships between and within Phacelia sections Whitlavia and Gymnobythus (Boraginaceae). Systematic Botany 34:737-746.

Heckard, L.R. 1960. Taxonomic studies in the Phacelia magellanica polyploid complex, with special reference to the California members. University of California Publications in Botany 32:1-126. 
KruckeberG, A.R. 1956. Notes on the Phacelia magellanica complex in the Pacific Northwest. Madroño 13: 209-221.

Nelson, A. 1902. Contributions from the Rocky Mountain Herbarium. III. Botanical Gazette 34:21-35.

Patterson, R., L.M. Garrison, and D.R. Hansen. 2012. Phacelia. Pages 485-501 in B.G. Baldwin, D.H. Goldman, D.J. Keil, R. Patterson, T.J. Rosatti, and D.H. Wilken, editors, The Jepson manual: vascular plants of California. 2nd edition. University of California Press, Berkeley, CA.

Rydberg, P.A. 1913. Studies on the Rocky Mountain Flora-XXIX. Bulletin of the Torrey Botanical Club 40:461-485.

Shelly, J.S. 1989. Biosystematic studies of Phacelia capitata (Hydrophyllaceae), a species endemic to serpentine soils in southwestern Oregon. Madroño 36:232-247.

[SEINET] SOUTHWEst EnVIRONMENTAL InFormation NETWORK. 2012-2016. [Accessed 2015-2016]. http:// swbiodiversity.org/seinet/index.php

Voss, J.W. 1937a. A revision of the Phacelia Crenulata group for North America. Bulletin of the Torrey Botanical Club 64:81-96.

Voss, J.W. 1937b. A revision of the Phacelia Crenulata group for North America (concluded). Bulletin of the Torrey Botanical Club 64:133-144.
WALDEN, G.K. 2010. Phylogeny of infrageneric relationships within Phacelia (Boraginaceae) inferred from chloroplast sequence data. Master's thesis, San Francisco State University, San Francisco, CA.

Walden, G.K., L.M. Garrison, F.W. Cipriano, G.S. Spicer, and R. Patterson. 2014. Phylogenies and chromosome evolution of Phacelia (Boraginaceae: Hydrophylloideae) inferred from nuclear ribosomal and chloroplast sequence data. Madroño 61:16-47.

Walden, G.K., and R. Patterson. 2012. Nomenclature of subdivisions in Phacelia (Boraginaceae). Madroño $59: 211-222$

Walden, G.K., R. Patterson, L.M. Garrison, and D.R. Hansen. 2013. Phacelia in Revision 1. Jepson Flora Project, editors, Jepson eFlora. [Accessed 27 July 2013]. http://ucjeps.berkeley.edu/TJM2_Supplement .pdf. http://ucjeps.berkeley.edu/cgi-bin/get_IJM.pl?tid $=9655$

Received 8 September 2015 Accepted 25 March 2016 